\title{
EFL STUDENTS' PERCEPTION ON TOEIC PRACTICE CLASS AT TWELFTH GRADERS SMK KESEHATAN HUSADA PRATAMA
}

\author{
Imam Fauzi \\ Serang Raya University \\ Email; imam unyur@yahoo.com
}

\begin{abstract}
Learning English language is much demanded and crucial for EFL students. Students are supposed to be able to prove their language skills through language proficiency test. TOEIC is one of the language proficiency tests that mostly EFL students especially vocational high school students need to learn and master it. However, the students often encounter some difficulties in conducting the TOEIC test. Improving students' comprehension about practicing the TOEIC test highly requires a good strategy. TOEIC practice class is considered to be one of appropriate approaches to be applied to encourage the students' comprehension. The purpose of the research is to investigate comprehensively whether there is any significant improvement of practicing TOEIC strategy on the students' listening comprehension of the twelfth grade students. This research applied descriptive qualitative approach that engages one group participated by 30 students of twelfth grade of SMK Kesehatan Husada Pratama. It can be seen that there was such significant improvements of practicing TOEIC strategy on the students' listening comprehension of the twelfth grade at SMK Kesehatan Husada Pratama academic year 2019/2020.
\end{abstract}

Key Words: TOEIC practice class, Listening Comprehension, Improvement

\section{INTRODUCTION}

In many countries, such as Indonesia, English is admitted as a foreign language. English is mostly used in English classrooms, while outside of the classroom, people commonly use their native language, Indonesian, for their daily communication. English is regarded as important foreign language. It is an evident that this language is taught in junior high school through university. The ability of students mastering English is commonly seen from the result of English proficiency test that is Test of English for International Communication (TOEIC). Nowadays, TOEIC is used to get a better job in English speaking countries. TOEIC is also used to apply for a job vacancy and most of Education schools especially vocational high school and polytechniques use this standardized test as a part of graduation requirements.

Learning English language highly requires the EFL learners to master four basic language competencies namely; Listening, Reading, Writing and Speaking. Listening is a part of language skills that is taught in almost vocational high schools (SMK). Listening is the oral skill that is important to study for the vocational high school students in order to make effective communication and to prepare them for their career after graduating from their school. Listening also has an important role because it is examined in the national examination. Listening comprehension is a process, a very complex process, and if we want to measure it, we must first understand how that process works. An understanding of what we are trying to 
Globish (An English-Indonesian journal for English, Education and Culture)

Vol. 9 No.2 July 2020

P-ISSN: 2301-9913, E-ISSN: 2597-9132

DOI: http://dx.doi.org/10.31000/globish.v7i2

measure is the starting point for test construction. The thing we are trying to measure is called a construct, and the test will be useful and valid only if it measured the right construct. Thus, the first task of the test developer is to understand the construct (Gary, 2001).

Furthermore, Lucy pollard as quoted from (Nurpahmi, 2015) Listening is one of the receptive skills and as such it involves students in capturing and understanding the input of English. Reading, the other receptive skill, involves students in understanding and interpreting the written word. Listening is probably more difficult than reading because students often recognise the written word more easily than they recognise the spoken word. Furthermore when reading, students can go back and reread a phrase whereas with listening they only get one chance. With reading, it's the reader who sets the pace whereas with listening it's the speaker or recording that sets the pace.

Students often encounter a problem in listening comprehension. It can be proven when they are given some English listening tasks. They still have trouble catching the actual sounds of the native language. They have to understand the meaning of every key word. They can understand if the native speakers speak slowly, they can't understand fast natural nativesounding speech. They need to hear things more than once in order to understand. If the listening goes on a long time, they get tired and find it more difficult to concentrate. Therefore, they need some effective strategies in order to be better at listening comprehension. According to ETS (2008:2) the TOEIC (Test of English for International Communication) test is an Englishlanguage proficiency test for people whose native language is not English. It measures the everyday English skills of people working in an international environment which is also given to the students of vocational high school (SMK) to know their proficiency and how well they can communicate in English. The TOEIC, or Test of English for International Communication, measures the non-native English-speaking test takers ability to use English in everyday workplace activities. The TOEIC also has six secondary purposes: (1) to verify the current level of English language proficiency; (2) to qualify for a new position and/or promotion in a company; (3) to enhance professional credentials; (4) to monitor progress in English; (5) to set learning goals; and (6) to involve employers in advancing English ability (ETS, 2015a, 2016a, p. 2).

Listening in the TOEIC Test has four parts namely Photographs, Question and Response, Short Conversations and Short Talks. And every part has its own strategy. Lougheed (2009:352) states that there are some skills in TOEIC strategy in TOEIC Listening Comprehension Test. The strategies in Photographs are 1.) Analyzing the Photo, 2.) Distinguishing Similar Sounds, and 3.) Making Inferences. The strategies in Question and Response are 1.) Distinguishing Wh- 
Globish (An English-Indonesian journal for English, Education and Culture)

Vol. 9 No.2 July 2020

P-ISSN: 2301-9913, E-ISSN: 2597-9132

DOI: http://dx.doi.org/10.31000/globish.v7i2

and Yes/No Questions, 2.) Identifying Homophones, and 3.) Recognizing Negative Meaning. The

Strategies in Short Conversations are 1.) Listening for the Main Idea, 2.) Understanding Wh-

Questions, and 3.) Understanding Modal Verbs. The strategies in Short Talks are 1.) Listening for Answer to Wh- Questions, 2.) Following the Questions Chronologically, and 3.) Making Inferences. Arbogast (2001:47-92) also states some strategies in TOEIC Listening Comprehension. The strategies in Photographs are 1.) Take a quick look at the photograph before you hear the four statements, 2.) Pay attention to similar sounding words with different meanings, and 3.) Listen carefully to each complete statement about the photograph. The strategies in Question and Response are 1.) Focus on the purpose of the question, 2.) Listen for question words, 3.) Pay close attention to words that sound alike. The Strategies in Short Conversations are 1.) Read the question first, 2.) Try to imagine the setting of the conversation and who is speaking, 3.) Look at all four choices carefully before answering. The strategies in Short Talks are 1.) Read the question first, 2.) Listen to the whole talk before trying to answer the questions, 3.) Pay special attention to the introduction and the first part of the talk.

Related literatures about TOEIC practice class in EFL learning contexts have been conducted by the many researchers as follows. (Hsieh, 2017) highlights in the research findings that students have positive views about the use of the TOEIC test scores for graduation and believe that preparing to take the test has a positive impact on their language proficiency and future employment prospects. The TOEIC test scores are also perceived favorably by the participants as having high levels of reliability and validity. Pan (2010) conducted a research about the use of TOEIC related to the students' communicative competency and test-taking. And the result of the research, TOEIC material was able to increase the students' communicative competency and test-taking significantly.

Further research pointed out that TOEIC test is one of language proficiency tests that can significantly measure the EFL learners language skill. Dealing with the significance of TOEIC practice, an other research finding revealed that students were considered intermediate to advanced level as their mean score of the pre-TOEIC score was 702 ranging from 515 to 945 . The results of the post-TOEIC showed that $78 \%$ of the students (28 out of 36 ) improved significantly from the mean score 702 to 766 by the average of 64 points. They also responded that the English-only classes help them improve and participate more actively as a form of role play and acting (Lee \& Jin, 2009). However, the researcher finds some problems in the EFL classroom such as EFL students do not use to learn TOEIC strategy, they have no ideas about which the most effective strategy of TOEIC test, they are still lack of listening skill, and they have big problems with the speed listening record because they can not catch the actual sound of 
Globish (An English-Indonesian journal for English, Education and Culture)

Vol. 9 No.2 July 2020

P-ISSN: 2301-9913, E-ISSN: 2597-9132

DOI: http://dx.doi.org/10.31000/globish.v7i2

native speakers. This research investigates whether there would be any improvements of EFL learners' listening competency and TOEIC results through the TOEIC practice class that has already spent time about four days intensively and included 30 vocational high school students of SMK Kesehatan Husada Pratama into TOEIC preparation class. The research problems are formulated in the following;

1. What does the students percieve about TOEIC practice class?

2. How does the TOEIC practice class can improve the students listening skill?

Based on the research formulated problems, the researcher would like to find out whether there would be any significant improvement of practicing TOEIC strategy on the students' listening comprehension of twelfth grade at SMK Kesehatan Husada Pratama in academic year 2019/2020. Relating to the language learning problems faced by the students, TOEIC practice class is expected to be applied appropriately to improve the students' listening comprehension and TOEIC scores. This research also is intended to investigate descriptively the EFL learners perceptions on the TOEIC practice class. Furthermore, this TOEIC practice class will effectively help the students to prepare them to face national examination, the TOEIC Test, and any other listening tasks. From the condition above, the researcher conducts a study towards the twelfth grade students of SMK Kesehatan Husada Pratama to identify the improvement of listening comprehension of the EFL students through TOEIC practice class.

\section{RESEARCH METHOD}

The research design in this study was descriptive qualitative approach. According to (Nassaji, 2015) Qualitative research, however, is more holistic and often involves a rich collection of data from various sources to gain a deeper understanding of individual participants, including their opinions, perspectives, and attitudes. The research approach used in this study was descriptive approach. To investigate and measure whether the TOEIC practice class has any effect on the students' listening comprehension, the researcher used 30 EFL nursy students collected through pre-test post-test design. The research was conducted at SMK Kesehatan Husada Pratama which is located on Jl. M. Muslich Lingkar Selatan, Serang, Kec. Serang, Kota Serang, Banten. It was conducted from January 10th to 14th, 2019. The research sample was 30 nursy students of twelfth grade of SMK Kesehatan Husada Pratama in academic year 2019/2020. Questionnaire about EFL students perceptions on TOEIC practice class that consist of 10 questions and TOEIC test are applied as the research instruments. The technique of data analysis used by the researcher was descriptive qualitative. This technique was used to prove the research questions based on the researcher mentioned previously. From this process, 
Globish (An English-Indonesian journal for English, Education and Culture)

Vol. 9 No.2 July 2020

P-ISSN: 2301-9913, E-ISSN: 2597-9132

DOI: http://dx.doi.org/10.31000/globish.v7i2

the researcher wanted to find out and observe whether there would be any significant or not by looking at the result of TOEIC pre-test and post-test.

\section{RESEARCH FINDINGS AND DISCUSSION}

In order to figure out whether the objectives of the research could be achieved or not, the researcher analyzed the test result of the pre-test and the post-test. The researcher conducted pre-test in order to find out the previous students' ability in listening before TOEIC practice class applied. The pre-test was administrated on December 10th, 2019 in Nursy Class of twelfth grade. The post-test was administrated on December 14th, 2019. The researcher conducted the post-test in order to find out their improvement in listening ability and also to make sure that TOEIC strategy can be used to improve the students' listening comprehension. After having observed the pre-test, post-test and applied the TOEIC practice class, the research findings revealed that the TOEIC practice class has significantly contributed much bigger effect on the students listening ability and their language skill integratedly. To respond the formulated research questions, it can be interpreted descriptively with the following;

\section{What does the students percieve about TOEIC practice startegy?}

Before the researcher tried to conduct the TOEIC practice class for students learning treatment, vocational high school students were getting confused on what the TOEIC terms and is used for at first time because of some logical reasons; fisrtly students have just heard about the term of TOEIC itself when they were participating in the first session of 5 days TOEIC practice class, secondly students have no ideas about doing the TOEIC test and vocational high school students at twelfth grade SMK Kesehatan Husada Pratama have never had any experiences to take TOEIC test and intensive program. The researcher designed three phases; pre-test, intensive learning process, and post test. After the TOEIC practice class has been conducted intensively at the twelfth grade students, to find out whether any positive improvements of students listening skill and their language capacity the researcher passed the questionnaire for students at aims of discovering students perceptions about whether any effectiveness of TOEIC practice class applied at twelfth grade students of SMK Kesehatan Husada Pratama. The questionnaire revelaed with the following table 1;

\begin{tabular}{|l|l|l|l|l|l|l|l|l|l|}
\hline No & Statements & \multicolumn{8}{|c|}{ Options } \\
\cline { 3 - 9 } & & Strongly & $\%$ & Agree & $\%$ & Disagree & $\%$ & Strongly & $\%$ \\
\hline
\end{tabular}


Globish (An English-Indonesian journal for English, Education and Culture)

Vol. 9 No. 2 July 2020

P-ISSN: 2301-9913, E-ISSN: 2597-9132

DOI: http://dx.doi.org/10.31000/globish.v7i2

\begin{tabular}{|c|c|c|c|c|c|c|c|c|}
\hline & & agree & & & & & & disagree \\
\hline 1 & $\begin{array}{l}\text { After you followed the } \\
\text { TOEIC practice class, } \\
\text { you are able to } \\
\text { understand the TOEIC } \\
\text { proficiency test }\end{array}$ & 12 & 40 & 13 & 43 & 5 & 17 & \\
\hline 2 & $\begin{array}{l}\text { TOEIC practice class } \\
\text { effectively assists you } \\
\text { to practice TOEIC test }\end{array}$ & 15 & 50 & 13 & 43 & 2 & 7 & \\
\hline 3 & $\begin{array}{l}\text { You are getting } \\
\text { increasingly motivated } \\
\text { to learn TOEIC strategy } \\
\text { through TOEIC practice } \\
\text { class }\end{array}$ & 14 & 47 & 16 & 53 & & & \\
\hline 4 & $\begin{array}{l}\text { TOEIC practice class is } \\
\text { very useful for you to } \\
\text { practice the TOEIC test }\end{array}$ & 19 & 63 & 11 & 37 & & & \\
\hline 5 & $\begin{array}{l}\text { I can learn easily } \\
\text { listening strategy of the } \\
\text { TOEIC proficiency test }\end{array}$ & 13 & 43 & 15 & 50 & 2 & 7 & \\
\hline 6 & $\begin{array}{l}\text { TOEIC practice class } \\
\text { enriches your own } \\
\text { language competencies } \\
\text { especially listening skill }\end{array}$ & 10 & 33 & 14 & 47 & 6 & 20 & \\
\hline 7 & $\begin{array}{l}\text { After following the } \\
\text { TOEIC practice class, I } \\
\text { am able to overcome } \\
\text { the problems how to } \\
\text { answer listening } \\
\text { sections of TOEIC test } \\
\text { name } \\
\text { ly; } \\
\text { question and resposes } \\
\text { and short conversation. }\end{array}$ & 11 & 37 & 16 & 53 & 3 & 10 & \\
\hline
\end{tabular}


Globish (An English-Indonesian journal for English, Education and Culture)

Vol. 9 No.2 July 2020

P-ISSN: 2301-9913, E-ISSN: 2597-9132

DOI: http://dx.doi.org/10.31000/globish.v7i2

\begin{tabular}{|l|l|l|l|l|l|l|l|l|}
\hline 8 & $\begin{array}{l}\text { Following the TOEIC } \\
\text { practice class positively } \\
\text { encourages you to } \\
\text { practice listening skill } \\
\text { through TOEIC } \\
\text { simulation test }\end{array}$ & 43 & 17 & 57 & & & & \\
\hline 9 & $\begin{array}{l}\text { TOEIC practice class } \\
\text { allows you to enrich } \\
\text { your self confidence at } \\
\text { doing TOEIC test }\end{array}$ & 15 & 50 & 12 & 40 & 3 & 10 & \\
\hline 10 & $\begin{array}{l}\text { TOEIC practice class } \\
\text { siginificantly helps you } \\
\text { to prepare your school } \\
\text { graduation }\end{array}$ & 16 & 53 & 14 & 47 & & & \\
\hline
\end{tabular}

Having observed the results of questionnaire, there were about $83 \%$ EFL students agreed that After they followed the TOEIC practice class, they were able to understand the TOEIC proficiency test. However, there were only $17 \%$ of EFL students stated that they have been trying hardly to learn to understand TOEIC strategy. The second point EFL students described there were $93 \%$ of them pointed out that TOEIC practice class effectively is able to assist them to practice and prepare the TOEIC test, 7\% of them had already requested that 5 days TOEIC practice class is not enough time for them to learn TOEIC strategy and hence some of them expected there would be special program monthly iniciated by school that facilitate students to practice and learn more about TOEIC startegy. Third point revealed that $100 \%$ of vocational high students twelfth grade of SMK kesehatan Husada Pratama entirely agreed and that TOEIC practice class can make them getting increasingly motivated to learn TOEIC strategy. Forth one, about $37 \%$ of them agreed that TOEIC practice class is very useful for them to practice TOEIC and 63\% of EFL students strongly agreed that TOEIC practice class can be much helpful because of some reasons; Fisrtly, after they followed the TOEIC practice class they are getting more interested in learning TOEIC startegy that make them easier to respond TOEIC questions in each section especially the listening comprehension. Secondly, TOEIC practice class facilitates the students to increase their four basic language competences listening, reading, writing and speaking. Thirdly, they feel engaged in the active learning activities through group work participation. Fifth point of 10 questions revealed that there were 93\% of EFL students agreed that TOEIC practice class can assist them to learn easily the listening strategy of the 
Globish (An English-Indonesian journal for English, Education and Culture)

Vol. 9 No.2 July 2020

P-ISSN: 2301-9913, E-ISSN: 2597-9132

DOI: http://dx.doi.org/10.31000/globish.v7i2

TOEIC proficiency test but only $7 \%$ of them commented that they need more listening exposures to upgrade their confidence in order to improve their listening skill. Sixth one is $80 \%$ of EFL students agreed that TOEIC practice class enriches their language competencies especially listening skill and $20 \%$ of them were still having big problems how to understand effectively the listening strategy of TOEIC test. Seventh one, $90 \%$ of students argued that after following the TOEIC practice class, they were able to overcome the problems how to answer listening sections of TOEIC test namely; Photograph, question and resposes and short conversation but $10 \%$ of them were still having some difficulties to comprehend the listening trics because only few of them had not participated fully the 5 days TOEIC practice class. The eighth point revealed that $100 \%$ of students highly agreed that following the TOEIC practice class positively encourages themselves to practice listening skill through TOEIC simulation test. Ninth point has already proven that $90 \%$ of them agreed that TOEIC practice class allows them to enrich their self-confidence at doing TOEIC test but $10 \%$ of students disagree because of some reasons; firstly some students are still getting confused to master the TOEIC trics, secondly some of them had some weaknesses at listening skill because they do not get used to practice English listening tasks even some students and thirdly they can not catch the actual listening sounds spoken by native speakers. The last point declared $100 \%$ of them agreed that TOEIC practice class siginificantly helps them to prepare their own school graduation.

Questionnaire of students responses about TOEIC practice class has obviously clarified that TOEIC practice class has siginificantly assisted the EFL students four major purposes; fisrt the EFL students would be able to construct their new knowledge about the useful trics of TOEIC test, second they feel highly interested in improving their major language competencies integratedly, third many students were enthusiastically engaged in the more active learning activities through TOEIC practice class, and lastly many of them expected to be able to participate the sessions up next so that they can practice much more listening skill, structure understanding and reading skill and easily accomplish the TOEIC test. To investigate much deeper investigation of students' improvement on their lisntening skill, it can be interprated as in the second research question;

\section{How does the TOEIC practice class can improve the students listening skill?}

To respond comprehensively the second research question, the researcher conducted Pre-test, learning treatments and Post- TOEIC test. This three phases have already revealed the research findings as described with the following;

\section{Mean Score of Pre- and Post-Test}




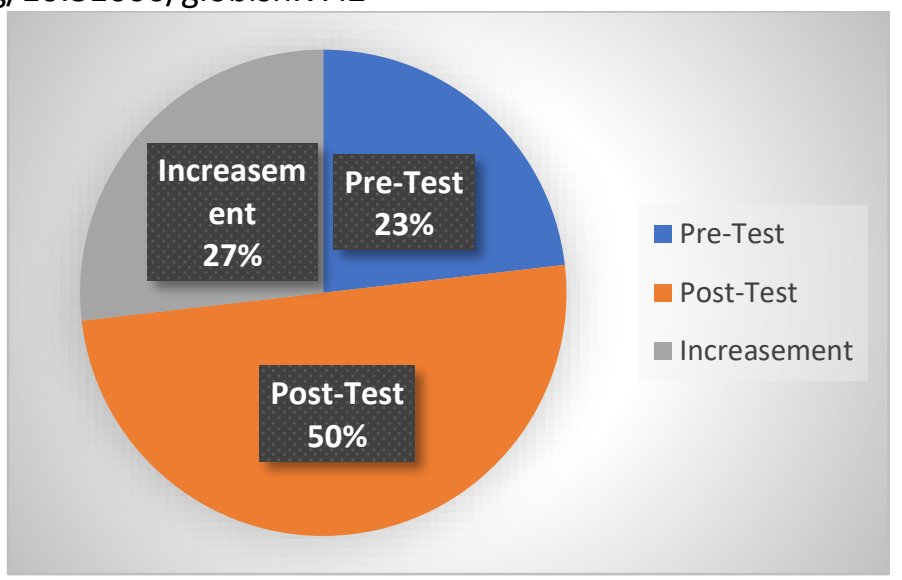

After the researcher conducted pre- and post test given in the TOEIC format, the findings has captured that most of students had made the significant improvement of TOEIC test results. It can be proven that there were $27 \%$ of $30 \mathrm{EFL}$ students were getting much better because some logical reasons; fisrtly many students were getting more interested in learning TOEIC strategy in TOEIC practice class that facilitate them to learn intensively in 5 day sessions along. From the result of post-test, it can be descriptively elaborated that $50 \%$ of 30 vocational high school students of SMK Kesehatan Husada Pratama mostly achieve the higher score of TOEIC test rather than pre-test. Most of them stated that TOEIC practice class gave them much influential treatments of learning the useful strategy of TOEIC test that made the EFL students easier to understand some typical questions of TOEIC test, learn some useful tips of TOEIC test, be more confident to practice TOEIC, and feel encouraged to improve their language ability. An other research finding revelaed that EFL students were getting much better at achieving TOEIC score and it can be clearly seen in the following chart;

\section{Mean score of Students Listening and Reading Converted Score Results}

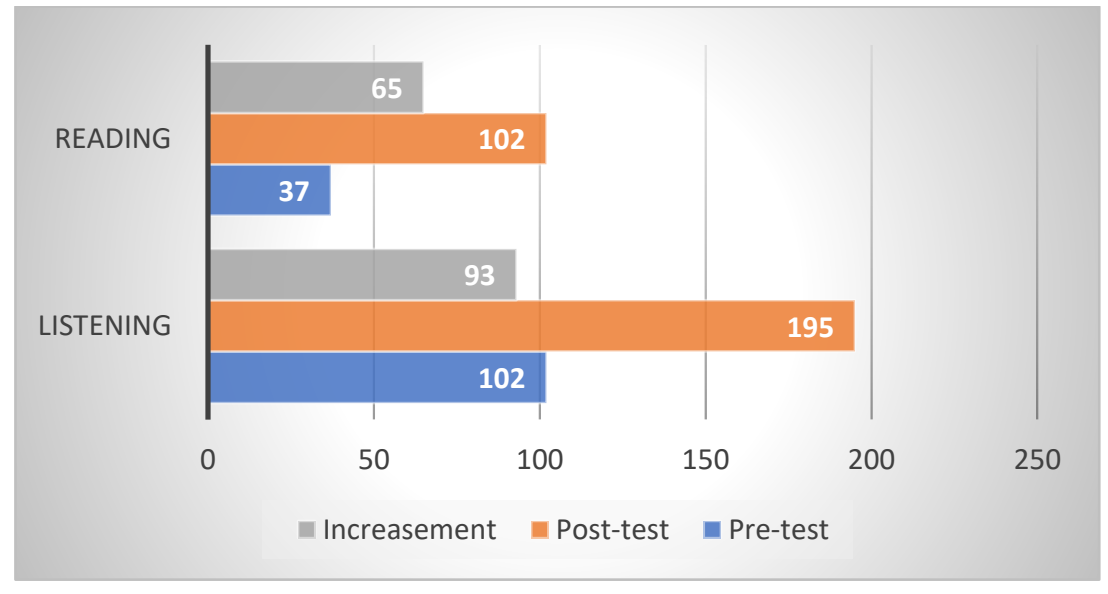

From the result of students listening and reading scores which have been converted into TOEIC standard rating scale, it can be elaborated that the twelfth grade vocational high school 
Globish (An English-Indonesian journal for English, Education and Culture)

Vol. 9 No.2 July 2020

P-ISSN: 2301-9913, E-ISSN: 2597-9132

DOI: http://dx.doi.org/10.31000/globish.v7i2

students of SMK Kesehatan Husada Pratama were doing their test with significant improvements. The average of reading score achieved by them was only $37 \%$ of $30 \mathrm{EFL}$ students get lower score in pre-test before they were given some beneficial treatments of 5 days TOEIC practice class. After given the learning treatments, they were getting better results of TOEIC score at reading about $102 \%$ and it increased about $65 \%$ of them made greater score of TOEIC test in the post test.

Having observed the score of listening section of TOEIC test, EFL students have been enthusiastically engaged in practicing the TOEIC test as one of recommended language proficiency tests that mostly is used for getting a new job or work situation. Listening score has been shown that after the learning treatments given to the EFL students, most of them reached higher score by looking at the increasement of students listening results about $93 \%$. Therefore, they expressed that the 5 sessions learning treatments can effectively encourage them to be more active at practicing some typical quetsions of TOEIC sections, expected this program would be continued and followed by some other students from different major studies at SMK Kesehatan Husada Pratama Kota Serang, and finally most of them feel more confident at doing the TOEIC test after joining intensively 5 sessions of TOEIC practice class.

\section{CONCLUSION}

A review from the research findings revealed that there was an increase of the students' scores in each section after being given the treatment. Listening comprehension has been achieved about 93 average increasement after the twelfth grade nurse vocational high school sctudents participated the TOEIC practice class. There were 65 average increasements reached by the EFL students because TOEIC practice class is able to encourage their interests in learning and understanding TOEIC useful strategy delivered in the 5 days learning treatments given by the researcher as EFT (English Foreign Teaching) practitioner, most of them were motivated to learn English language through learning and practicing TOEIC helpful tricks, the treatments enrich them some more knowledges of preparing the TOEIC test, and most of EFL students appreciated the program and expected to follow the TOEIC practice class again in the next term. Further findings proven that $27 \%$ of $30 \mathrm{EFL}$ students were getting much better because some logical reasons; fisrtly many students were getting more interested in learning TOEIC strategy in TOEIC practice class that facilitate them to learn intensively in 5 day sessions along. From the result of post-test, it can be descriptively elaborated that $50 \%$ of 30 vocational high school students of SMK Kesehatan Husada Pratama mostly achieved the higher score of TOEIC test 
Globish (An English-Indonesian journal for English, Education and Culture)

Vol. 9 No.2 July 2020

P-ISSN: 2301-9913, E-ISSN: 2597-9132

DOI: http://dx.doi.org/10.31000/globish.v7i2

rather than pre-test. It can be concluded that the implementation of TOEIC practice class can significantly improve the students' listening comprehension. According to the result of this research, it states that there is significant improvement of practicing TOEIC practice class on the students' listening comprehension. That is why the use of TOEIC practice class in academic purpose especially in listening should not be neglected. To create a comfortable environment in teaching, the researcher suggests that the teacher be selective in applying appropriate techniques in listening as the students need to be ready in doing listening test and the readiness can be obtained when they feel comfortable. The students also should not be busy with their own business during the learning process when they are not familiar or do not like with the material or the technique used. In contrary, they should be able to adapt with the new techniques and materials used as fast as possible to reach better learning achievement and EFL learning and teaching purposes.

\section{REFERENCES}

Buck, Gary. 2001. Assessing Listening. Cambridge: Cambridge University Press.

Educational Testing Service. (2015a). Examinee handbook - Listening \& reading. Retrieved from www.ets.org/Media/Tests/TOEIC/pdf/TOEIC LR examinee handbook.pdf.

ETS. 2008. TOEIC; Examine Handbook Listening \& Reading. Educational Testing Service.

Hsieh, Ni-Ching. 2017. The Case of Taiwan: Perceptions of College Students About the Use of the TOEIC Tests as a Condition of Graduation. Research Gate Journal. Vol 17(45).

Lee, E \& Jin, S. 2009. English-only Classes and Student Improvement on TOEIC. Journal of PanPacific Association of Applied Linguistics, 13(1), 2338.

Lougheed, Lin. 2009. Building Skills for the New TOEIC Test 2nd Ed. New York: Pearson Education

Nassaji, H. 2015. Qualitative and descriptive research: Data type versus data analysis. Journal of Language Teaching Research, Vol. 19(2) 129-132.

Nurpahmi, Sitti. 2015. Improving Listening Skill by Activating Students' Prior Knowledge. Research Gate Journal Volume I, Number 01. p 28-38.

Pan, Yi-Ching. 2010. Enhancing Students' Communicative Competency and TestTaking Skills through TOEIC Preparation Materials. TESOL Journal Vol. 3, December. pp. 81-91. http:www.tesol-journal.com 